\title{
Constitutional Complexities of European Democracy in Light of the 2014 European Parliament Elections
}

\author{
Anna Kocharov*
}

Table of Contents
A. Introduction
B. Legitimacy and the Union
C. Accountability of the European Commission to the European Parliament
D. Constitutionality of the "Spitzenkandidaten" Arrangement
I. The Letter of Article 17(7) TEU: the Power to Propose Candidates and Interinstitutional Balance
II. The Spirit of Article 17 TEU: Role of the European Commission and its Independence
III. The Spirit of the Treaties: Democracy and the Union 455
E. Accountability in the Constitutional Construct of Europe 457
F. Conclusion

And when he hath made an end of atoning for the holy place, and the tent of meeting, and the altar, he shall present the live goat:

and Aaron shall lay both his hands upon the head of the live goat, and confess over him all the iniquities of the children of Israel, and all their transgressions, even all their sins; and he shall put them upon the head of the goat, and shall send him away by the hand of a man that is in readiness into the wilderness:

and the goat shall bear upon him all their iniquities unto a solitary land: and he shall let go the goat in the wilderness.

Leviticus 16:20-22

\section{A. Introduction}

On 27 June 2014 the President of the European Commission was for the first time nominated against an express vote by two Member States. This nomination followed the practice invented by the European Parliament (EP) a year earlier, ${ }^{1}$ whereby the European political parties nominate their candidates for the presidency of the European Commission ahead of

* Law Department, European University Institute. I would like to thank Christian Calliess, Marise Cremona, Enzo Moavero Milanesi, Paolo Ponzano and Bruno de Witte for invaluable insights on the various aspects of this paper; any omissions remain with the author alone.

1 European Parliament resolution of 4/7/2013 on improving the practical arrangements for the holding of the European elections in 2014 (2013/2102 INL). 
the 2014 elections to the EP, with the candidate put forward by the party that wins the most seats in the EP to "be the first to be considered" for the post of President of the European Commission. This practice completes the attempts to construct venues for Voice of citizens directly on the Union level. Giving citizens the power to influence Europe's politics and policies - through institutional arrangements on Union level such as extending the powers of the EP and the European citizens' initiative - is thought to increase legitimacy of Europe.

Two claims are made in this connection. First, that giving more Voice to citizens would increase democratic legitimacy of the EU; second, that the Spitzenkandidaten arrangement respects the Treaties. ${ }^{2}$ This article will analyze both claims. It will be argued that legitimacy of the Union and its policies cannot be separated from the Treaties. By twisting the letter and spirit of the Treaties, the new arrangement for nominating the President of the Commission undermines the legitimacy of Europe's constitutional construct. Giving citizens a Voice directly on the Union level goes against the constitutional arrangement of the Treaties, which leave decisive policy-making power with national governments in the European Council.

The article begins by outlining the problem of legitimacy in the EU: the many meanings associated with the concept, the institutional and constitutional setting that raised the issue. Understanding legitimacy in the context of the Union is fundamental for evaluating the substance of the Spitzenkandidaten arrangement.

Second, brief historical background of the accountability of the Commission to the EP is given. This analysis demonstrates that already prior to the 2014 elections, the Commission was accountable to the EP and the Parliament successfully exercised its powers in this regard.

Third, constitutionality of the Spitzenkandidaten arrangement is tested against the letter and spirit of the Treaties. This section aims to go beyond the mere wording of Article 17 TEU, pointing out how it interplays with other Treaty provisions and with the overall structural framework created for the Union in the EU Treaties this could pose problems of constitutional law. Respecting the letter and spirit of the Treaties is fundamental for raising the legitimacy of the Union and its institutions.

Finally, possible implications for legitimacy of the EU are considered. It will be argued that an alternative solution for enhancing democratic legitimacy in the Union is possible. This solution lies with the European Parliament, which currently lacks the power to determine a policy agenda for the Union - a power which remains with the European Council. This makes the national governments, and not the European Commission, the real "government" of Europe, pointing to futility of the Spitzenkandidaten reform.

2 Weiler, The political and legal culture of European integration: An exploratory essay, International Journal of Constitutional Law 9 (2011), pp. 678-694; Editorial, European Parliament Elections 2014: Europe's Fateful Choices, European Journal of International Law 24 (2013), pp. 747-753. 


\section{B. Legitimacy and the Union}

Ever since the Single European Act and the Maastricht Treaty, concerns over legitimacy of the Union flourished. ${ }^{3}$ The reasons for these concerns are two structural changes to Europe's Union that were reflected in these Treaties and elaborated in all the Treaties that succeeded them. The first concerns the reach of Union's policies and powers and can be termed as policy interdependence. ${ }^{4}$ Policy interdependence takes place independently from the decision-making procedure on Union level (unanimity, consensus or qualified majority voting) and refers to the factual capacity of each national polity to regulate within its jurisdiction (to implement a policy choice). This capacity can be undermined as a result of externalities and interdependence between the national polities created by European integration, whereby regulatory decisions by one polity may affect the regulatory capacity of the other. A good example of policy interdependence are the Schengen area and the Euro, where immigration and budgetary decisions respectively of one Member State may produce effects on the policies pursued by another Member State. The problem caused by policy interdependence can be resolved by shifting policy-making from national level to the Union. National polities and national political processes would then lend their legitimacy to the Union and its policies ${ }^{5}$ as long as these are adopted by unanimity or consensus.

The second structural evolution of the Union that gives rise to legitimacy concerns is the method of decision-making. The passage from unanimity or consensus to qualified majority vote (QMV) in the Council ${ }^{6}$ implies that Union policies no longer derive legitimacy from the national political process because individual Member States may find themselves bound against their will as represented by their governments in the Council. This creates interdependence between the national and European levels of decision-making: on the one hand, legitimacy of the national political process is undermined because the national polity can be bound against its will; on the other hand, an alternative source of legitimacy is needed on the Union level to compensate for this loss. Several options are available for this alternative legitimacy source:

3 Ex multis Moravcsik, Reassessing Legitimacy in the European Union, Journal of Common Market Studies 40 (2002), pp. 603-624; Majone, The Common Sense of European Integration, Journal of European Public Policy 13 (2006), pp. 607-626; Foellesdal/Hix, Why There is a Democratic Deficit in the EU: A Response to Majone and Moravcsik, Journal of Common Market Studies 44 (2006), pp. 533-562; as regards European institutions and the EP specifically see Dann, The Political Institutions, in: von Bogdandy/Bast (eds.), Principles of European Constitutional Law, 2010. For the view that the EU need not be democratic along the model of nation states see Majone, Dilemmas of European Integration: The Ambiguities and Pitfalls of Integration by Stealth, 2005, chapter 2.

4 Chronologically, this is the second element that gained prominence with the abolition of internal borders and the introduction of the single currency.

5 Article 10(2) TEU secures representative democracy in the Union on two levels: "Citizens are directly represented at Union level in the European Parliament. Member States are represented in the European Council by their Heads of State or Government and in the Council by their governments, themselves democratically accountable either to their national Parliaments, or to their citizens."

6 Although QMV was foreseen already in the original 1957 EEC Treaty, it was not exercised until the 1986 Single European Act. 
1. Messianic or promise legitimacy corresponds to the original promise of Europe to deliver peace and prosperity to its peoples. ${ }^{7}$ To the extent that this promise is fulfilled, this type of legitimacy is transformed into output or result legitimacy. The original promise of European integration has been an economic revival after World War II and to ensure a lasting peace among Member States of the Community; ${ }^{8}$ these goals have obviously been fulfilled.

2. Substantive or output legitimacy links the acceptance of public power to the results that this power achieves. It is also the extent to which the polity is capable of autonomous self-governance. ${ }^{9}$ Output legitimacy will be high for popular measures that achieve their promised results and low for unpopular policies or failure to deliver (the latter will also undermine messianic legitimacy). The onset of the financial crisis and the need for unpopular austerity measures have undermined this source of legitimacy for the EU.

3. Formal legitimacy or consent describes whether the powers were constituted and laws enacted following formal rules, procedures, and constitutional guarantees. It is the legalistic side of process legitimacy that does not necessarily translate into the acceptance of resulting rules. ${ }^{10}$ However, lack of compliance with the constitutional letter and spirit of the Treaties would undermine this legitimacy source.

4. Process or input legitimacy seeks to achieve the acceptance of public power through ensuring interest representation and participation in the political process. The idea is to ensure a voice to those who are bound by the exercise of public power and whose acceptance this power is seeking. Such reforms as citizens' initiative and subsidiarity review by national parliaments seek to further process legitimacy; low turnout of voters in the EP elections, on the contrary, undermines it. Process legitimacy, to be effective, needs to be backed up by accountability.

5. Political legitimacy or accountability is the capacity of citizens to remove the government from power when the latter no longer represents their voice. ${ }^{11}$ This mechanism aims to ensure that the government acts in the interest of the citizens and does not abuse its powers.

6. Adjudicative legitimacy corresponds to the capacity of polity members to enforce limited government in court, in particular through the protection of the individual from the state and minorities from majorities, which ensure the good functioning of the political

7 Weiler, (fn. 2), p. 683.

8 Recital 8, Preamble to the 1957 EEC Treaty; the Schuman Declaration (Paris on 9 May 1950), see European Parliament - Committee on Institutional Affairs, Selection of texts concerning institutional matters of the Community from 1950 to 1982, 1982, p. 47 et seq.

9 Walker, Constitutionalizing Enlargement, Enlarging Constitutionalism, European Law Journal 9 (2003), p. 368, who cites Scharpf, Governing in Europe: Effective and Democratic?, 1999, chapter 1.

10 Weiler, The Transformation of Europe, Yale Law Journal 100 (1991), p. 2469.

11 Weiler/Haltern/Mayer, European Democracy and its Critique Five Uneasy Pieces, EUI Working Paper RSC No. 95/11, p. 9: "In its present state, no one who votes in the European elections has a strong sense at all of affecting critical policy choices at the European level and certainly not of confirming or rejecting European governance." 
process. ${ }^{12}$ Directly effective rights of citizens secured in the Treaties serve to raise this type of legitimacy in the EU.

7. Social legitimacy is the result of all the previous methods of increasing the authority of public power as reflected in public opinion surveys ${ }^{13}$ and in the actual acceptance of the resulting norms. ${ }^{14}$ Here, the 2013 surveys were worrying: only $39 \%$ of Europeans expressed trust in the European Parliament while $48 \%$ distrusted it; $12 \%$ said that they expect nothing from the EU. ${ }^{15}$

"Giving a face" to EP elections ${ }^{16}$ aimed to create a "difference to Europe and in Europe whether and how the people vote for the European Parliament". ${ }^{17}$ By establishing a more direct link between outcome of EP elections and the nomination of President of the Commission, it is hoped to link elections to Union policies, offer voters a visible choice between the different European parties, increase voter turnout, citizen representation and accountability of the EU executive. It would therefore tackle the disinterest of citizens with the Union and the rise of Eurosceptic parties across Member States.

\section{Accountability of the European Commission to the European Parliament}

Originally under the EC Treaty, the members of the Commission were appointed by common accord by the governments of the Member States ${ }^{18}$ while the President of the Commission was to be appointed from the Commission members after consultation of the entire college. ${ }^{19}$ The Assembly (which preceded the European Parliament) could pass a motion of censure of the Commission obliging it to resign as college; ${ }^{20}$ the Court of Justice could compulsorily retire individual members of the Commission. ${ }^{21}$

The Maastricht Treaty reversed the order of appointment procedure. Under Article 158(2) EC as amended:

"The governments of the Member States shall nominate by common accord, after consulting the European Parliament, the person they intend to appoint as President of the Commission.

12 Poiares Maduro, Sovereignty in Europe: the European Court of Justice and the Creation of European Political Community, in: Volcansek/Stack Jr (eds.), Courts Crossing Borders, Blurring the Lines of Sovereignty, 2005; de Búrca/Gerstenberg, The Denationalization of Constitutional Law, Harvard International Law Journal 47 (2006), pp. 243-262.

13 Weiler, (fn. 10), p. 2469.

14 What Tuori calls "empirical legitimacy", see Tuori, Critical Legal Positivism, 2002, p. 244.

15 Standard Eurobarometer 80, Autumn 2013, European Citizenship, p. 7.

16 Borrell Fontelles, The Future Role of the European Parliament, in: Tsoukalis/Emmanouilidis (eds.), The Delphic Oracle on Europe: Is There a Future for the European Union?, 2011, p. 54.

17 For analysis of the "opportunities and possible risks related to prospect of turning the European elections into personalized contest for the presidency of the European Commission" see Weiler, Challenges to electoral participation in the European elections of 2014, Restoring Electoral Faith: Prospects and Risks in AFCO Report Strengthening European Democracy: Citizens' Participation, Which challenges do we face at the European Elections of 2014?, 2013, European Parliament doc. PE 493.036.

18 Article 158 EC Treaty 1957.

19 Article 161 EC Treaty 1957.

20 Article 144 EC Treaty 1957.

21 Article 160 EC Treaty 1957. 
[...] The President and the other members of the Commission [...] nominated [by governments in consultation with the nominee for President of the Commission] shall be subject as a body to a vote of approval by the European Parliament."

This procedure was followed for the appointment of the Santer Commission in January 1995. The Court of Justice remained in charge of compulsory retirement of individual members of the Commission, while the possibility of the Council to suspend Commissioners was removed. ${ }^{22}$ The power of the European Parliament to censure the Commission as college remained in place; while a motion of censure was never carried, the mere threat thereof caused the Santer Commission to resign in March 1999.

The Amsterdam Treaty further increased parliamentary control over the Commission. The new Article 214(2) EC required not only consultation of the EP when nominating the President of the Commission but also EP approval; the provision on approval by EP of the Commission as a whole remained unchanged. The Prodi Commission was appointed using this procedure in September 1999. The EP retained its power to dismiss Commission as college. Article 219 EC as amended by the Amsterdam Treaty specified that the Commission President shall provide "the political guidance" for work of the Commission.

Another amendment to Article 214(2) EC followed with the Treaty of Nice. While leaving the powers of the EP unaltered, the procedure for appointment of all Commissioners was changed from common accord to qualified majority voting in the Council. At the same time, the EP exercised its power of approval of the Commission as college postponing the appointment of the first Barroso Commission from October to November 2004. ${ }^{23}$ The Parliament exercised this power again during the appointment of the second Barroso Commission in early 2009. Both in 2004 and 2009, the political stripe of the President of the Commission followed the European party with most seats in the EP as well as the governments of most Member States in the Council, although both times the support of other parties in the EP was necessary since no party had an absolute majority in the Parliament. The Treaty of Nice also introduced the power of the Commission President to request resignation of individual Commissioners "after obtaining the approval of the College". ${ }^{24}$

Therefore, already prior to the Lisbon Treaty, the Commission was accountable to the EP both as college and its individual members, ${ }^{25}$ while nomination of the President of the Commission and the college required the approval of the majority in the Parliament. On several occasions already the EP successfully exercised its powers in this regard.

Despite these developments, the Laeken Declaration of the European Council restated the link between the democratic deficit of European institutions and the procedure of appointment of the President of the Commission. ${ }^{26}$ The draft Treaty establishing a Constitu-

22 Article $160 \mathrm{EC}$ as amended in Maastricht.

23 For a detailed account see AFCO working document by MEP Andrew Duff, How the European Parliament approves the European Commission of 30/11/2004, DT $548974 E N$.

24 Article 217(4) EC.

25 Framework Agreement on relations between the European Parliament and the European Commission, OJ L 304 of 20/11/2010, p. 47, point II(5).

26 Annexes to the Presidency conclusions, European Council meeting in Laeken 14 and 15 December 2001, SN 300/1/01 REV 1, p. 22 et seq. 
tion for Europe introduced the new phrasing ${ }^{27}$ that was carried over into the Constitutional Treaty ${ }^{28}$ Article I-27:

"The President of the European Commission

1. Taking into account the elections to the European Parliament and after having held the appropriate consultations, the European Council, acting by a qualified majority, shall propose to the European Parliament a candidate for President of the Commission. This candidate shall be elected by the European Parliament by a majority of its component members. If he or she does not obtain the required majority, the European Council, acting by a qualified majority, shall within one month propose a new candidate who shall be elected by the European Parliament following the same procedure.

2. The Council, by common accord with the President-elect, shall adopt the list of the other persons whom it proposes for appointment as members of the Commission. They shall be selected, on the basis of the suggestions made by Member States, in accordance with the criteria set out in Article I-26(4) and (6), second subparagraph.

The President, the Union Minister for Foreign Affairs and the other members of the Commission shall be subject as a body to a vote of consent by the European Parliament. On the basis of this consent the Commission shall be appointed by the European Council, acting by a qualified majority.

3. The President of the Commission shall:

(a) lay down guidelines within which the Commission is to work;

(b) decide on the internal organisation of the Commission, ensuring that it acts consistently, efficiently and as a collegiate body;

(c) appoint Vice-Presidents, other than the Union Minister for Foreign Affairs, from among the members of the Commission.

A member of the Commission shall resign if the President so requests. The Union Minister for Foreign Affairs shall resign, in accordance with the procedure set out in article I-28(1), if the President so requests."

With the Lisbon Treaty amendment, the first paragraph of this article became Article 17(7) TEU:

"Taking into account the elections to the European Parliament and after having held the appropriate consultations, the European Council, acting by a qualified majority, shall propose to the European Parliament a candidate for President of the Commission. This candidate shall be elected by the European Parliament by a majority of its component members. If he does not obtain the required majority, the European Council, acting by a qualified majority, shall within one month propose a new candidate who shall be elected by the European Parliament following the same procedure.

$[\ldots]$

The President $[\ldots]$ and the other members of the Commission shall be subject as a body to a vote of consent by the European Parliament. On the basis of this consent the Commission shall be appointed by the European Council, acting by a qualified majority."

The European Commission reinterpreted this provision. In order "to foster the emergence of a genuine European political sphere", the Commission called on the political parties to

27 CONV 850/03 of 18/7/2003, Article 26.

28 OJ C 310 of $16 / 12 / 2004$, p. 3. 
nominate their candidates for the President of the Commission in the context of 2014 elections. ${ }^{29}$ The following year the Commission was even more explicit:

"Each political party should make known its candidate for President of the Commission during the election process. In accordance with the Treaty, the outcome of the European elections should play a key role in determining which candidate becomes President of the Commission." 30

The European Parliament took up the idea and urged "the European political parties to nominate candidates for the Presidency of the Commission" with the expectation that "those candidates [...] play a leading role in the parliamentary electoral campaign, in particular by personally presenting their programme in all Member States of the Union". 31

In the same Resolution, the Parliament called

"for as many members of the next Commission as possible to be drawn from Members of the European Parliament, to reflect the balance between the two chambers of the legislature."

Neither Commission Communications nor Resolutions of the European Parliament produce legal effects and as such cannot be challenged before the Court of Justice of the EU. ${ }^{32}$ Further, the Council did not issue any document in response to this initiative to express its formal opinion or consent. Thus, while a political agreement between the Commission and the Parliament is in place, there is no formal interinstitutional agreement between them and nothing documents any legal, formal nor political agreement on the Spitzenkandidaten arrangement between these two institutions and the Council. Therefore, unlike previous cases where the Council indicated its readiness to challenge interinstitutional arrangements between the Commission and EP, ${ }^{33}$ no such formal challenge is possible for the Spitzenkandidaten arrangement. Nevertheless, the Court of Justice would be able to fulfill its constitutional role of "ensur[ing] that in the interpretation and application of the Treaties the law is observed" 34 by reviewing the act of appointment of the President of the Commission by the European Council pursuant to the last paragraph of Article 17(7) TEU.

29 Communication from the Commission, A blueprint for a deep and genuine economic and monetary union, COM (2012) 777 final/2 of 30/11/2012, p. 37.

30 Communication from the Commission to the European Parliament, the Council and the European Economic and Social Committee and the Committee of the Regions, Preparing for the 2014 European elections: further enhancing their democratic and efficient conduct, $\operatorname{COM}$ (2013) 126 final of $12 / 3 / 2013$, p. 6.

31 European Parliament resolution of 22/11/2012 on the elections to the European Parliament in $2014(2012 / 2829$ (RSP)).

32 Article 263 TFEU.

33 For instance, as regards the Framework Agreement on relations between the European Parliament and the European Commission, OJ L 304 of 20/11/2010, p. 47, the Council indicated readiness to commence infringement proceedings against the Commission and the EP for "modify[ing] the balance established in the Treaties between the institutions" to the prejudice of the Council, for "accord[ing] powers to the Parliament not conferred in the Treaties" and for "limit[ing] the autonomy of the Commission and its President", see Council of the European Union, Opinion of the Legal Service on the Draft Framework Agreement between the European Parliament and the Commission, doc. $15018 / 10$ of $18 / 10 / 2010$.

34 Article 19(1) TEU. 


\section{Constitutionality of the "Spitzenkandidaten" Arrangement}

The Spitzenkandidaten arrangement is founded on an erroneous interpretation of Article 17(7) TEU taken out of context of the Treaties and the interinstitutional balance established therein. It is based on the excessive emphasis given to the phrase "[ $t$ ]aking into account the elections to the European Parliament" contained in Article 17(7) TEU in disregard over other provisions contained in this and other Articles of the Treaties.

\section{The Letter of Article 17(7) TEU: the Power to Propose Candidates and Interinstitutional Balance}

The procedure for appointing the President of the European Commission contained in Article 17(7) TEU is the following:

1. The European Council proposes the candidate by qualified majority.

2. The European Parliament elects the candidate by absolute majority.

3. The Council, on the basis of suggestions made by Member States and by common accord with the President pre-elect, proposes the college.

4. The European Parliament consents to the entire college (the President of the Commission included) by absolute majority.

5. The European Council appoints the college by qualified majority.

This procedure amounts to co-decision between the Member States in the European Council and Council on the one hand and the European Parliament on the other. This interpretation is corroborated by Declaration 11 on Article 17(6) and (7) TEU attached to the Treaty of Lisbon. While not legally binding, Declaration 11 obliges the two institutions to collaborate on the nomination, placing the responsibility for "the smooth running of the process leading to the election of the President of the European Commission" jointly on the EP and Council.

Article 17(7) TEU unequivocally reserves the power to propose candidates for President of the European Commission to the European Council:

"the European Council [...] shall propose to the European Parliament a candidate for President of the Commission".

There is no priority given to any candidates advanced by the EP or any other institution or political party. Giving the Parliament an upper hand in nominating the candidate for President of the European Commission would reverse the procedure set out in the Treaties, a change requiring a formal Treaty amendment. Nominating the President of the Commission according to the Spitzenkandidaten arrangement without Treaty amendment would undermine formal legitimacy of EU institutions and of the national political processes in the course of which the peoples of Europe ratified the Treaties. Potentially, such an appointment would be reviewable by the Court of Justice as an act that produces legal effects and changes interinstitutional balance established in the Treaties.

The obligation to take account of EP elections should be read together with the rest of Article 17(7) TEU, which provides that the candidate gather majority support in the EP. The purpose of the requirement to take account of the EP election is to ensure that the Council nominates a candidate who can realistically gather majority support in the Parlia- 
ment, as opposed to nominating minority candidates who a priori cannot be expected to meet this requirement. The importance of this joint reading of the two provisions becomes especially apparent once the first candidate for President of the Commission does not gather a simple majority in the EP, since the European Council has a one-month time limit to propose each subsequent candidate. ${ }^{35}$ The obligation to take account of the political composition of the EP therefore aims to expedite the appointment procedure.

The requirement to take account of EP elections is not a special rule for the appointment procedure but a specific application of the general principle of mutual sincere cooperation between the EU institutions contained in Article 13(2) TEU:

"Each institution shall act within the limits of the powers conferred on it in the Treaties, and in conformity with the procedures, conditions and objectives set out in them. The institutions shall practice mutual sincere cooperation."

This reading is corroborated by the fact that the two obligations - to take account of EP elections in nominating the candidate for Presidency of the Commission on the one hand, and the duty of mutual sincere cooperation between EU institutions on the other-converge in their historic origins. Both were introduced into the Treaties with the draft Constitution and, in their legally binding form, in the Lisbon Treaty - yet, both obligations have preConstitution origins in the interinstitutional practice. As regards the political affiliation of the President of the Commission, it has been noted above that prior to 2014, in all the cases where an election by the EP was required, the appointee belonged to the party with most seats in the European Parliament (although this coincided also with the governing parties in most Member States). As regards mutual sincere cooperation between European institutions, its importance was recognized by the Court of Justice on the basis of a joint declaration by the European Parliament, the Council and the Commission. ${ }^{36}$ Both pertain to the functioning of the Union and its institutions as well as to the conferral and division of powers between them according to the provisions of the Treaties. ${ }^{37}$ The Court of Justice

35 Article 17(7) § 1 TEU.

36 Joint Declaration by the European Parliament, the Council and the Commission on various measures to improve the budgetary procedure, OJ C 194 of 28/7/1982, p. 1 (which opens with the phrase "Whereas harmonious cooperation between the institutions is essential to the smooth operation of the Communities") and ECJ, case 204/86, Greece v Council, ECR 1988, 5323, para. 16; see also ECJ, case C-65/93, EP v Council, ECR 1995, I-643, para. 23 on the "mutual duty of sincere cooperation" in the course of interinstitutional dialogue.

37 It is significant in this regard that proposals to amend the wording "Taking into account the elections to the European Parliament" and the role of the EP in nominating Commission President contained in Article 26 of the draft Constitution in a way that would reverse the institutional balance giving the power to nominate candidates for President of the Commission to the European Parliament and leaving the European Council the role of confirming the President-elect were not carried into the final version of the Constitution. Proposals to reduce or even eliminate the role of the EP were equally rejected. See ex multis suggestions for amendment of Article 18 bis by Valdo Spini; Péter Balázs, Hannes Farnleitner, Sandra Kalniete, Jan Kohout, Ivan Korčok, Rytis Martikonis, Lennart Meri, Dimitrij Rupel, Teija Tiilikainen; Kimmo Kiljunen, Matti Vanhanen, Riitta Korhonen and Antti Peltomäki; Vytenis Povilas Andriukaitis and Gintautas Šivickas; William Abitbol - for a full list of proposals see http://european-convention.europa.eu/EN/amendments/amendmentsf9f8.html?content=41899\&lang=EN (1/10/2014). The relevance of travaux preparatoires for identifying the purpose of Treaty provisions has been confirmed in ECJ, case C-370/12, Pringle, para. 58. 
might therefore be able to review the act of appointment of President of the Commission for compliance with Article 13(2) TEU in view of the institutional balance observed in the course of this appointment. ${ }^{38}$

\section{The Spirit of Article 17 TEU: Role of the European Commission and its Independence}

The purpose of conditioning the Presidency of the Commission on the outcome of elections to the EP is to create a more direct link between the outcome of EP elections and policies of the Commission. ${ }^{39}$ Yet, were such a link is created, it would mutate accountability of the Commission to the Parliament into "taking instructions", failing to respect the balance between accountability and independence of the European Commission set out in the Treaties. According to Article 17(3) TEU,

"The members of the Commission shall be chosen [...] from persons whose independence is beyond doubt.

In carrying out its responsibilities, the Commission shall be completely independent. [...] the members of the Commission shall neither seek nor take instructions from any Government or other institution, body, office or entity. They shall refrain from any action incompatible with their duties or the performance of their tasks."

Independence of the Commission is crucial for its ability to fulfill the institutional role assigned to it in the Treaties. The Commission has a number of tasks that require a high level of actual and perceived independence, in particular:

"The Commission shall promote the general interest of the Union and take appropriate initiatives to that end. It shall ensure the application of the Treaties, and of measures adopted by the institutions pursuant to them. It shall oversee the application of Union law under the control of the Court of Justice of the European Union. It shall execute the budget and manage programmes. It shall exercise coordinating, executive and management functions, as laid down in the Treaties. With the exception of the common foreign and security policy, and other cases provided for in the Treaties, it shall ensure the Union's external representation. It shall initiate the

38 In a pending - ECJ, case C-28/12, Commission v Council - the Commission inter alia alleges that "the Council infringed [...] the principle of sincere cooperation laid down in Article 13(2) TEU. The Council should have exercised its powers so as not to circumvent the institutional framework of the Union and the Union procedures set out in Article 218 TFEU" in so far as "it transpires from Article 218(2) and (5) TFEU that the Council is the institution designated to authorise the signing and provisional application of agreements. Therefore, the decision should have been solely taken by the Council and not also by the Member States, meeting within the Council." For an opinion that "institutional balance does not entail a kind of one-way traffic in favour of the European Parliament" see Prechal, Institutional Balance: A Fragile Principle with Uncertain Contents, in: Heukels/Blokker/Brus (eds.), The European Union after Amsterdam: A Legal Analysis, 1998, p. 278. Klamert, The Principle of Loyalty in EU Law, 2014, p. 216 : "always favouring the legal basis granting more rights of participation to the Parliament is not supported by arguments of institutional balance".

39 European Parliament, Practical arrangements for the holding of the European elections in 2014 European Parliament, Resolution 2013/2102(INI) of 4/7/2013, P7_TA-PROV(2013)0323. For a discussion of this objective in light of the Union structure contained in the Treaties see Editorial, (fn. 2), pp. 747-753. 
Union's annual and multiannual programming with a view to achieving interinstitutional agreements." 40

Because the EP votes on the candidate for President of the Commission twice - first individually and subsequently on the whole Commission as college - this amounts to an instruction to the President-elect from the EP to form a certain type of Commission. This instruction is further backed by the possibility to sanction the President-elect together with the entire college on the second vote. This also gives minority parties in the Parliament new bargaining power over the nomination of the college, shifting the power to propose all candidates for membership of the Commission from the Council to the EP - a shift not contained in the Treaties. ${ }^{41}$

Both the President of the Commission and individual Commissioners "shall refrain from any action incompatible with their duties" and "may not, during their term of office, engage in any other occupation, whether gainful or not". ${ }^{42}$ A failure to fulfill "the conditions required for the performance of his duties" by any member of the college enables the Court of Justice "on application by the Council acting by a simple majority or the Commission, compulsorily retire him". ${ }^{43}$

The obligation of the Council to take into account EP elections is only one of the criteria for nominating the candidate. Another major requirement is contained in Article 17(3) TEU:

"the members of the Commission shall be chosen on the ground of their general competence".

This includes the President of the Commission. Declaration 11 lists the "backgrounds of the candidates" as a focus factor in choosing the nominee, alongside the EP elections. Additionally, the nomination should take account of "the need to respect the geographical and demographic diversity of the Union and its Member States", balancing with the nominations for President of the European Council and High Representative of the Union for Foreign Affairs and Security Policy. ${ }^{4}$

Even if Treaty requirements regarding independence of the Commission were set aside, the arrangement could lead to a major interinstitutional crisis. This is so because the President of the Commission cannot nominate the Commissioners but only accord on nominations made by Member States, ${ }^{45}$ what José Manuel Durão Barroso famously called "a blind date". ${ }^{46}$ Thus, even if the party that gains the most seats in the EP nominate a candidate who then gathers support of the majority in the Parliament and qualified majority in the Council, this President might not be able to wrestle 28 governments appointing Commissioners from other parties. Potentially, this could lead to two forms of an interinstitutional crisis. First, were a partisan President of the Commission belongs to a political stripe dif-

40 Article 17(1) TEU.

41 This would contradict in particular Article 24 TFEU: "the Members of the Commission shall be chosen on the basis of a system of rotation established unanimously by the European Council".

42 Article 245 TFEU.

43 Article 247 TFEU.

44 Declaration 6 on Articles 15(5) and (6), 17(6) and (7) and 18 TEU.

45 Article 17(7) TEU.

46 European Voice of 3/12/2009, p. 6 cited in Peterson, The College of Commissioners, in: Peterson/ Shackleto (eds.), The Institutions of the European Union, 2012, p. 108. 
ferent from most governments in the Council, a disagreement on the college could delay appointment of the Commission. Second, once the college comprising Commissioners from different political parties is appointed, they might not necessarily follow the policies put forward by a partisan President. Partisan discord could undermine collegiality of the Commission, which its President has a duty to ensure. ${ }^{47}$ It could also be more difficult for a partisan President of the Commission to request resignation of individual Commission$\mathrm{ers}^{48}$ who belong to a different party, as this could be seen as a bet on new appointees closer to her political stripe. Also censuring the Commission by the $\mathrm{EP}^{49}$ could become more difficult. Commission President belonging to the party that wins most seats in the EP is bound to pose questions of democratic legitimacy: can minority parties in Parliament collude to dismiss the President nominated by the party with most seats, i.e. elected by Union citizens? The proposal that the Parliament be able to dismiss the Commission only when the EP can propose a new candidate for President ${ }^{50}$ would not solve this problem.

\section{The Spirit of the Treaties: Democracy and the Union}

A systemic issue lurks behind these provisions. The European Communities were founded with the finality - the source of EU's messianic legitimacy - to ensure prosperity and peace between Member States. Throughout the process of European integration, one of the main concerns has been to prevent domination of some Member States over others. Democracy was not only absent from this original project of European integration but it was so on purpose: the Union would enable Member States to counteract the eventuality of another Hitler coming to power through democratic process. An intergovernmental Community would counterbalance the democratic nation state. The Commission plays a central role in this construct as a neutral guarantor of common European interest and of interests of small Member States. ${ }^{51}$ For instance, the Commission has extensive supervisory powers in the areas of competition ${ }^{52}$ and budgetary oversight. ${ }^{53}$ Enlargement of the European Union to 28 Member States and extension of Union powers into more politically sensitive regulatory fields increase heterogeneity in circumstances and interests within the Union, raising importance of the neutrality of the Commission further. Creating a direct link between the Head of the European executive - the actions of the Union - and the outcome of democracy

47 Article 17(6)(b) TEU. In this regard, the Code of Conduct of Commissioners, C (2011) 2904, p. 3 specifies that "Commissioners are expected to defend and support the decisions taken by the College. Their Commission duties must prevail over party commitment."

48 Article 17(6) TEU.

49 Article 17(8) TEU.

50 Speech of Commission President Barroso at Humboldt University Berlin on 8/5/2014, SPEECH/ 14/355, p. 16.

51 Article 4(2) TEU: "The Union shall respect the equality of Member States before the Treaties as well as their national identities, inherent in their fundamental structures, political and constitutional, inclusive of regional and local self-government. It shall respect their essential State functions, including ensuring the territorial integrity of the State, maintaining law and order and safeguarding national security."

52 See e.g. Articles 96, 106, 108 TFEU.

53 See e.g. Article 126 TFEU. 
would negate the very construct and purpose of the Union: similar to creating a European polity, ${ }^{54}$

"it would be more than ironic if a polity set up as a means to counter the excesses of statism ended up coming round full circle and transforming itself into a (super) state." 55

Linking policies pursued by the Commission to the outcome of EP elections would present major structural problems for the Union under the current Treaties. The nature and institutional setting of the Union established in the Treaties render the Commission very dissimilar of the governments even in federal states, reflecting the fact that the EU is a "union among the peoples of Europe". The role of the Commission is neither equivalent nor comparable to a national government: the Lisbon Treaty reserves the power to set policy agenda to the European Council, so the functions exercised by governments in Member States are effectively split between the European Council and the Commission. The Council and EP are different from e.g. the Senate and the House of Representatives in the U.S. because the representation in both EU "chambers" reflects both Member States and their populations. This leaves small Member States more vulnerable than less populous states of the U.S., ${ }^{56}$ requiring a special role of the Commission.

In view of this special role, Article 17(3) TEU provides that

"the members of the Commission shall be chosen on the ground of their [...] European commitment".

Giving priority to the candidate of the party that wins the most seats in the EP would open the door - at least hypothetically - to the majority being the Eurosceptics. While Eurosceptics are not outlawed from the political process in the EU or any Member State (unlike the more extreme right-wing parties in some Member States), their candidates would be precluded from consideration not only for presidency of the Commission ${ }^{57}$ but also for any

54 Something that is attempted with the introduction of Union citizenship ever since the Treaty of Maastricht, compare specifically the definition of members of European Parliament as "representatives of the Union's citizens" in Article 14(2) TEU Lisbon Treaty with their previous definition as "representatives of the peoples of the States brought together in the Community" in Article 189 EC before Lisbon. Creation of a single European political process would pose problems as regards the language(s) of the debates among the candidates for Presidency of the Commission; failing to fully use the languages of smaller Member States for such debates could undermine not only the democratic legitimacy of the European political process but also linguistic and cultural diversity among Member States protected by Articles 3(3) TEU and 24 TFEU.

55 Weiler, The constitution of Europe: "Do the new clothes have an emperor?" and other essays on European integration, 1999, p. 341.

56 Under the new QMV rules, the relative importance of small Member States fell while the relative importance of medium and large Member States increased. The QMV rules in force from 2014, provide that three large Member States (representing $35 \%$ of Union population) may block the adoption of secondary EU law. This leaves small Member States little leverage while Member States with large populations retain much of their power despite the passage from unanimity to QMV.

57 This is also because, according to EP resolution of 4/7/2013 on improving the practical arrangements for the holding of the European elections in 2014 (2013/2102/INL), the candidates for President of the Commission would be nominated by European parties, while not all the political forces competing in EP elections qualify as European parties under Article 3 Regulation 2004/2003/EC on the regulations governing political parties at European level and the rules regarding their funding as amended by Regulation 1524/2007/EC, OJ L 343 of 27/12/2007, p. 5. 
member of the college. As a result, the credibility (and legitimacy!) of the arrangement will be hampered by its applicability to some political parties but not others. ${ }^{58}$ This would clearly be incompatible both with democracy and rule of law, and would amount to giving the right to vote but the right to stand for office.

Nor would the linking of Commission's policies to EP elections be desirable in democratic terms. Winning the most seats in the Parliament - the requirement for giving priority to one party candidate over another - is not the same as absolute majority. Even if the other parties back the candidate for President of the Commission so that the absolute majority required for appointment is gathered, this would be an arrangement very different from coalition governments formed in Member States. Since the President of the Commission can only accord with nomination of the college by Member States but has no power to propose own candidates, the composition of the college is not likely to reflect majority coalition in the European Parliament. Were a partisan President of the Commission is to shape the policy agenda of the Union along her party lines - as opposed to merely "lay down guidelines within which the Commission is to work" 59 - such agenda-setting could disempower the other parties in the Parliament, especially the smaller parties who cannot hope to be the largest in the EP. This risks reducing the EU (and, by implication also the national political processes) to a two-party system, muting the votes of citizens who vote for medium and smaller parties, and concentrating excessive power in a single office. Failing to further the lines of her coalition party (for instance because none of the Commissioners share the latter) might risk a loss of support for the President of the Commission in the Parliament and a motion of censure for the entire college. This would not be undemocratic because however democracy is defined, a party that gathers less than $50 \%$ support from citizens should not be imposing its views on the majority.

\section{E. Accountability in the Constitutional Construct of Europe}

The Lisbon Treaty preserves and strengthens the role and capacity of national polities and national political processes in shaping Union policies. To the extent that creation of a European democratic process by citizens directly on Union level substitutes rather than compliments the national political processes, the former would strike against the constitutional structure established in the Treaties. Considering the importance of national political process in the constitutional construct of Europe sealed in the Treaties, shifting political accountability from Member States to the EU undermines democracy and legitimacy on both levels of power.

The Lisbon Treaty protects and furthers the governing capacity of the national political processes in three ways. First, it codifies preexisting practice of having policy choice made

58 This is independently and additionally to the legitimacy issues that may arise if the candidate of the party that wins most seats in the EP fails to gather the absolute majority in the Parliament or qualified majority in the Council and therefore does not get appointed as President of the Commission.

59 Article 17(6)(a) TEU. 
by national governments in the European Council. ${ }^{60}$ Although not endorsed with legislative powers, the European Council is now an official institution of the Union responsible for providing "the Union with the necessary impetus for its development" and defining "the general political directions and priorities thereof". ${ }^{61}$ These policy-choice decisions are taken in the European Council by consensus. ${ }^{62}$ This is especially important for those policies of the Union that lack functional Treaty objectives to direct European policy choice. ${ }^{63}$ National policy preferences, elaborated in the course of the national political process, feed into the development of shared European policy. This underlines the importance of accountability of national governments on the national level.

Second, the Lisbon Treaty introduced pluralism as one of the foundations of Europe's constitutional construct alongside democracy, equality and the rule of law. ${ }^{64}$ Followed by EU's commitment to "equality of Member States before the Treaties" and respect for their national identities, constitutional and political, ${ }^{65}$ pluralism thus refers to plurality of national constitutions and national political processes that these constitutions regulate. Equality of Member States before the Treaties implies equality of policy choices elaborated in their national political processes, so that no national policy preference can legitimately dominate others. ${ }^{66}$ It is this plurality of national policy preferences and "competing interpretations of the common good" 67 that feed into the process of developing European policies. This way, legitimacy and good functioning of the national political processes is intertwined with legitimacy of the EU. Accountability on the national level is therefore fundamental for legitimacy of Union's policies.

Third, Union law recognizes and advances the importance of good functioning the national political process in Europe's constitutional construct. Democracy, rule of law, respect for human rights and protection of minorities are an integral part of the Copenhagen criteria $^{68}$ that must be fulfilled for joining the EU. Fulfillment of these criteria ensures that the national political process of all Member States leads to elaboration of legitimate national preferences for policy choice, preferences that feed into the policies shaped on Union level. Through operation of Union law, membership in the European legal order eliminates "externalities" between the national political processes. ${ }^{69}$ This is achieved by securing non-

60 Articles 15, 16(6), 22, 26 TEU, Articles 68, 121, 148 TFEU, as well as the capacity of national governments to enter between themselves into international treaties outside EU law, such as the Fiscal Compact.

61 Article 15(1) TEU.

62 Article 15(4) TEU.

63 For an example of such Union policy see Kocharov, Subsidiarity after Lisbon: Federalism without a Purpose?, in: Azoulai/Boucon/Millet, Deconstructing EU Federalism through Competences, EUI Working Paper Law 2012/06.

64 Article 2 TEU.

65 Article 4 TEU.

66 Poiares Maduro, Il rischio del "maggioritarismo intergovernativo", Quaderni costituzionali/ a. XXIII of 3/9/2003, p. 657

67 Poiares Maduro, In Search of a Meaning and not in Search of the Meaning: Judicial Review and the Constitution in Times of Pluralism, Wisconsin Law Review 2013, p. 544.

68 European Council in Copenhagen 21-22 June 1993, Conclusions of the Presidency, SN 180/1/93 REV 1, p. 13.

69 Poiares Maduro, We the Court, 1998, p. 156 et seq. 
discrimination on the grounds of nationality in cross-border situations, where the interests that belong to one national political process fall under the regulatory reach of another national political process. This corrects the shortcomings in interest representation in national political processes thereby enhancing their functioning and legitimacy.

Creating an alternative European democratic process that would compete with and substitute the national political process is incompatible with Europe's constitutional construct. Accountability of politicians in the national political process emerges as key for legitimacy of EU policies. Avoiding accountability in the national political process by shifting policies up to the EU is a temptation for national governments noted already since the Maastricht Treaty. ${ }^{70}$ Union law should counteract such temptations. Under the Spitzenkandidaten arrangement, however, accountability for European policies will fall on the President of the Commission, who does not make policy choices. Appointing an EU "face" who could be sanctioned for the failure of collective policies shaped by national governments in the European Council would reduce accountability of real policy makers. This aggravates instead of solving democratic deficit on both EU and national levels. Legitimacy of the Union and national political processes is undermined instead of furthered.

\section{F. Conclusion}

On its face, the Spitzenkandidaten arrangement for nominating the candidate for President of the Commission will change little for representation and accountability. Already before the Treaty of Lisbon, the Commission was accountable to the EP, both its President and the entire college approved by the Parliament, while the President of the Commission belonged to the party with the most seats in the EP. However, it has been argued here that this arrangement creates a number of constitutional and democratic challenges. These challenges could undermine rather than further legitimacy of the Union and its policies.

The arrangement is incompatible with the letter and spirit of the Treaties. It changes the institutional balance of the EU and alters the nature of the Union so deeply as to amount to Treaty amendment outside the procedure provided therefor in the Treaties. The procedure established in Article 17(7) TEU is twisted and impartiality of the Commission questioned. A major institutional crises could result and replicate on Union level the malfunctions of national democracies against which Union law is supposed to guard.

In terms of increasing accountability and input legitimacy, the Spitzenkandidaten arrangement is fallacious in its design. Because the real power to set policy agenda for the Union lies with the national governments in the European Council, increasing accountability of EU officials does little to promote European governance that respects the preferences of Union citizens. It is, indeed, highly doubtful whether accountability can be shifted from the national level to the EU inasmuch as democratic accountability should

70 Bermann, Taking Subsidiarity Seriously: Federalism in the European Community and in the United States, Columbia L. Rev. 94 (1994), p. 361; for the latest see Weiler, (fn. 17), p. 6 and Speech of Commission President Barroso, (fn. 50), p. 11. 
follow actual decision-makers. This is not the role of the European Commission. ${ }^{71}$ By placing accountability where responsibilities do not lie, the arrangement creates a European scapegoat for the failures of national governments and national democracies. Given the institutional and representation structure established in the Treaties, the arrangement allows national governments to continue using the EU level for the adoption of laws that are controversial in their Member States; this undermines further the debate on these policies in the national democratic processes and, as a result, limits the capacity of the peoples of Europe to elaborate shared European policies. Hardly any form of legitimacy is served as a result.

Two venues are open for making the EU more accountable to its citizens. First, the agenda-setting power could be shifted from the European Council to the Parliament. This would ensure that accountability follows power, as opposed to personifying accountability without corresponding power shift. Such a change would strike against the current letter and spirit of EU constitutional design and would require a Treaty amendment but, more importantly, it would require a shared perception on behalf of all the peoples of Europe as a single unified group for the purpose of majority rule - exactly the opposite of what is currently the case. ${ }^{72}$ Alternatively and second, national campaigns for EP elections could focus on the performance of national politicians in the EU, including both national governments in the Council and European Council and national Members of the European Parliament. This would enhance the currently dominating national dimension of EP elections ${ }^{73}$ positioning the prevailing domestic issues ${ }^{74}$ in European context. Such enhancement would correspond to the actual Treaties but would require transparency in the work of the Council and the European Council so that a meaningful debate about it can take place on the national level. Linking EP elections to the performance of national governments and Members of the European Parliament on EU issues is exactly the opposite from the decoupling between the national governments and the EU that is the substance of the Spitzenkandidaten arrangement.

71 "The introduction of the co-decision procedure in the EU decision-making and the functioning in practice of the inter-institutional system have transformed the role of the Commission from that of an autonomous initiator to that of a reactive initiator." Ponzano/Hermanin/Corona, The Power of Initiative of the European Commission: A Progressive Erosion?, 2012, www.notreeurope.eu/media/commission_power_of_initiative_ne_feb2012.pdf?pdf=ok (1/10/2014). See also Christiansen, The European Union after the Lisbon Treaty: An Elusive 'Institutional Balance'?, in: Biondi/Eeckhout/Ripley (eds.), EU Law After Lisbon, 2012, p. 237.

72 See Standard Eurobarometer 80, Autumn 2013, European Citizenship.

73 Reif/Schmitt, Nine Second-order Elections, European Journal of Political Research 8 (1980), pp. 3-44; Jacobs, European Parliament Elections in Times of Crisis, Intereconomics 1 (2014), p. 7: "A related risk often referred to by political scientists is that voters may perceive these as 'second-order elections' in which national governments are not directly at stake and that this will either lead to indifference and abstention or else provide an ideal opportunity to register a protest vote against incumbent governments and establishment parties."

74 Piedrafita/Renman, The 'Personalisation' of the European Elections: A half-hearted attempt to increase turnout and democratic legitimacy?, EPIN Paper No. 37, 2014, p. 3: "elections to the EP to second-order elections largely focused on domestic rather than European issues". 